https://doi.org/10.15407/scine17.04.003

KACHYNSKYI, V. S. (https://orcid.org/0000-0001-9695-6434),

KOVAL, M. P. (https://orcid.org/0000-0003-2066-3365),

and KLYMENKO, V. I. (https://orcid.org/0000-0002-8709-5924)

The E. O. Paton Electric Welding Institute of NAS of Ukraine,

11, Kazymyra Malevycha St., Kyiv, 03650, Ukraine,

+380 44200 4779, office@paton.kiev.ua

\title{
DEVELOPMENT OF TECHNOLOGY AND CREATION OF TEST EQUIPMENT FOR PRESSURE WELDING OF HIGH-LOAD THIN-WALLED HETEROGENEOUS STEEL TUBULAR PARTS
}

Introduction. Magnetically impelled arc butt welding (MIAB) method differs from the existing arc methods by high productivity, stable quality of welded joints, high degree of mechanization and automation of the technological process and so on. Welding is performed automatically, which significantly reduces the influence of the operator-welder on the quality of welded joints. The optimal values of the magnetic field induction components for thin-walled tubular parts with a diameter of $212 \mathrm{~mm}$ are determined. The basic technological parameters on welding of tubular details in stationary conditions are defined, it is: qualitative preparation of end faces of pipes; optimal distribution of induction of the control magnetic field (CMF); arc voltage; the magnitude and order of programming the welding current; the rate of closure of the arc gap in the process of upset. The influence of liquid metal melt in the arc gap during upset on the formation of welded joints of pipes is determined. Metallographic studies showed no defects in the weld line and a relatively small area of thermal impact. Mechanical properties of welded joints at the level of mechanical properties of the base metal. Studies have been conducted to determine the parameters that affect the stable movement of the arc along the thin-walled edges of tubular parts and the influence of liquid metal melt in the arc gap during heating on the formation of welded joints.

Problem Statement. Pipes of small diameters (up to $220 \mathrm{~mm}$ ) are used in various industrial enterprises and construction of pipelines. The work requires high-performance automatic welding methods that allow obtaining stable and reliable welded joints.

Purpose. The purpose is to raise labor productivity and to save materials by using equipment and technology for press welding of magnetically controlled arc of thin-walled tubular parts.

Materials and Methods. Steel thin-walled tubular parts with a diameter of $42 \mathrm{~mm}$ and $212 \mathrm{~mm}$, with a wall thickness of 2.5... $3 \mathrm{~mm}$ were used for research on press welding. To create a control magnetic field, magnetic systems for tubular parts with a diameter of $212 \mathrm{~mm}$ were developed. Experimental welding was performed and samples of welded joints of pipes with a diameter of $212 \mathrm{~mm}$ with a wall thickness of $3 \mathrm{~mm}$ were investigated. In the course of the research, the main parameters are recorded and the welding process is controlled by computer.

Citation: Kachynskyi, V. S., Koval, M. P., and Klymenko, V. I. Development of Technology and Creation of Test Equipment for Pressure Welding of High-Load Thin-Walled Heterogeneous Steel Tubular Parts. Sci. innov. 2021. V. 17, no. 4. P. 3-10. https://doi.org/10.15407/scine17.04.003 
Results. The main technological parameters: preparation of pipe ends; magnitude and distribution of control magnetic field induction; the arc voltage; the magnitude and order of programming the welding current; the rate of closure of the arc gap during upset, which affects the formation of welds have been determined. The experimental industrial technology for welding of thin-walled tubular details with a diameter up to $212 \mathrm{~mm}$ for the purpose of its industrial use and the concept of the welding equipment has been developed, patents for the invention have been received.

Conclusions. The mechanical and metallographic tests have shown that the properties of welded joints are at the level of the properties of the base metal. The use of press welding technology for tubular parts increases productivity and automates the welding process. The influence of the bandwidth of the liquid molten metal in the arc gap, while heating, on the formation of welded joints of pipes has been experimentally established. The main technological parameters and their influence on the quality of welded joints in the process of heating, the ends, and the upset of thin-walled tubular parts have been determined. Experimental industrial technology for press welding of thin-walled tubular parts has been developed and industrial tests have been conducted, in accordance with the customer's requirements.

Keywords: high-load thin-walled tubular parts, press welding by magnetically controlled arc, welding techno$\log y$, and formation of welded joints.

The object of this research is the joint of thin-walled tubular parts for work under high loads by pressure welding with a magnetically controlled arc.

The purpose of this research is to increase the productivity of press welding of thin-walled tubular parts by of a magnetically controlled arc and to obtain high-quality joints.

Introduction. Pipes of small diameters up to $220 \mathrm{~mm}$ are used in various industrial enterprises and construction of pipelines. Traditionally, for welding pipes, the manual arc welding method and the automatic welding in a protective gas are used. These works require skilled welders or highly efficient automatic welding techniques that provide stable and reliable welds. For a long time, the

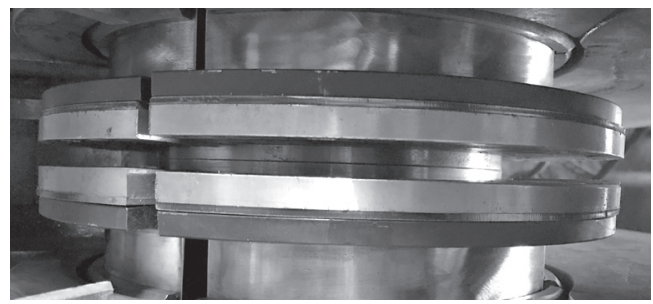

Fig. 1. System for creating a control magnetic field
Paton Welding Institute has been conducting research works on the development of automated welding processes [1-3]. One of the developed processes is press welding by a magnetically controlled arc (the MIAB welding).

Materials and Methods. Steel thin-walled tubular parts with an outside diameter of 42 and $212 \mathrm{~mm}$, with a wall thickness of $2.5 \ldots 3 \mathrm{~mm}$ are used to conduct research on press welding with a magnetically controlled arc. The chemical composition is shown in Table 1.

To create a control magnetic field, magnetic systems for pipes with a diameter of $212 \mathrm{~mm}$ have been designed (Fig.1).

To conduct research, a cycle diagram of the process for programming the technological parameters of the MIAB cycle has been developed (Fig. 2). At the beginning of the process, during time $t_{1}$, the pipes butts are compressed to ensure reliable contact of their butts. The welding DC power supply is activated. The pipes are spread on the arc gap and the arc is excited. During time $t_{2}, t_{3}$, and $t_{4}$, the pipe butts are heated by welding current $\mathrm{I}_{1}, \mathrm{I}_{2}$,

Table 1. Steel chemical composition, \%

\begin{tabular}{|c|c|c|c|c|c|c|c|c|c|c|}
\hline Type of steel & $\mathrm{C}$ & $\mathrm{Si}$ & Mn & $\mathrm{P}$ & S & $\mathrm{Cu}$ & $\mathrm{Ni}$ & $\mathrm{Cr}$ & Mo & $\mathrm{Al}$ \\
\hline St20 & 0.20 & 0.24 & 0.47 & 0.015 & 0.016 & 0.05 & 0.05 & 0.25 & 0.05 & 0.01 \\
\hline 35 & 0.39 & 0.35 & 0.75 & 0.35 & 0.04 & 0.25 & 0.25 & & & \\
\hline
\end{tabular}




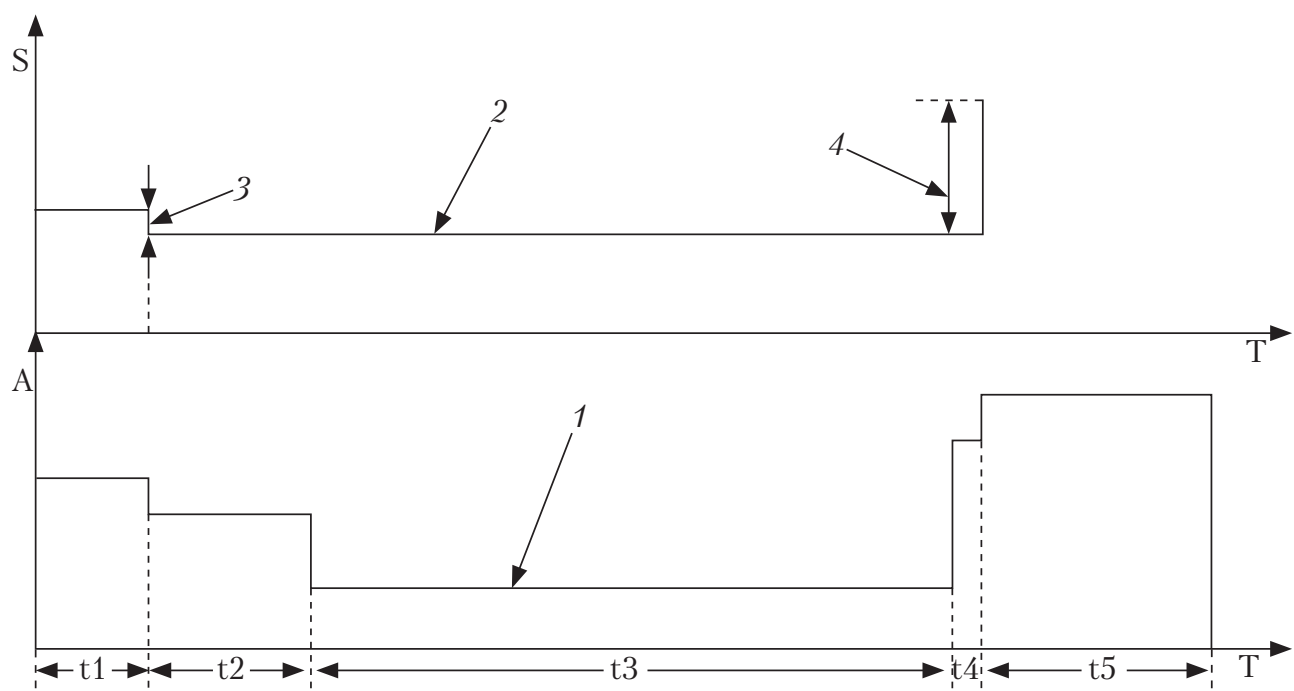

Fig. 2. Cyclogram control of the welding process, where: 1 - welding program; 2 - process stages; 3 - arc voltage; 4 - upset

and $\mathrm{I}_{3}$, according to the settings of the technological parameters. Having reached the specified heat, the upset is done. Past time $t_{5}$, the welding rectifier is deactivated, and so does the upsetting drive, at time $t_{6}$. The welding cycle is complete.

Uniform and intensive heating of the pipe surfaces to be welded depends on stable movement of the arc under the influence of an external magnetic field. The speed of arc movement depends on the arc current, induction of the control magnetic field (CMF), the size of the gap between the ends, and the quality of the butt preparation.

The stability of the arc depends on the magnitude of the arc gap. If the gap is less than $1.2 \mathrm{~mm}$, the movement of the arc is accompanied with short circuits of the arc gap, and increase in the gap by more than $2.5 \mathrm{~mm}$ leads to disruption of the arc. It has been established that in the case of the MIAB welding of pipes with a diameter of $212 \mathrm{~mm}$, the gap shall be equal to $1.9 \pm 0.2 \mathrm{~mm}$. The magnitude of the radial component of the induction of CMF in which the arc moves steadily, at the ends, ranges within $120-140 \mathrm{mT}$. Welding is performed without the use of a gas protective mix.

The welding process is influenced by various factors. This necessitates quality control of welded joints. The main condition for the formation of a welded joint is joint plastic deformation of the welded parts. The formation of joints is influenced by the following factors: the condition of the butt surfaces (initial surface temperature, the presence of micro-irregularities, a layer of oxides and contaminants); temperature distribution at the pipe butts; the magnitude and the nature of the plastic deformation of the butts during upsetting.

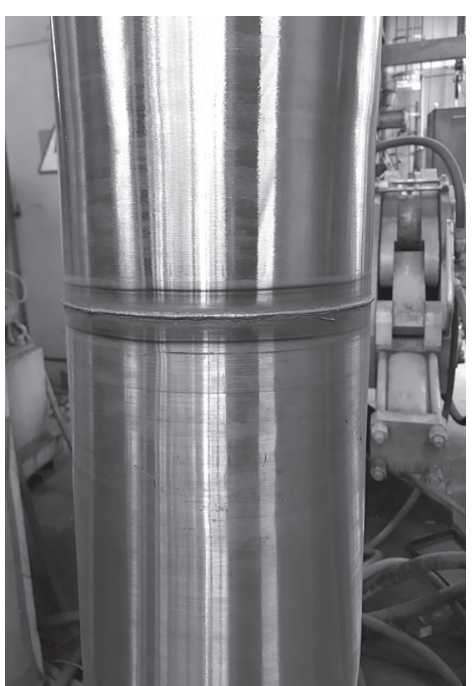

Fig. 3. Welded pipe joint, diameter of $212 \times 3 \mathrm{~mm}$ 


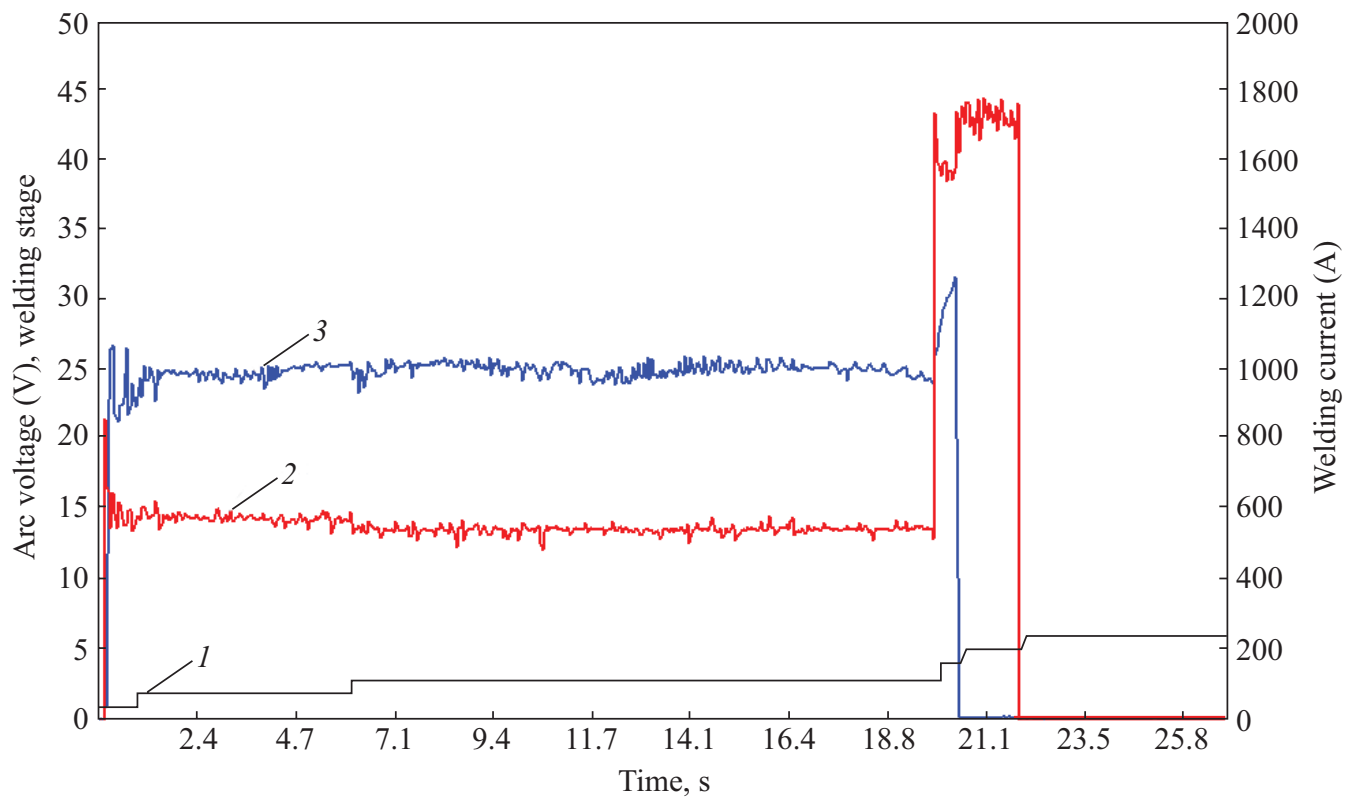

Fig. 4. Record of the main parameters of pipe welding, where: 1 - process stages; 2 - welding current; 3 - voltage arc

Experimental welding has been done, and the samples of welded joints of pipes with a diameter of $212 \mathrm{~mm}$ with a wall thickness of $3 \mathrm{~mm}$ have been studied (Fig. 3). In the course of the research, the main parameters are recorded and controlled by computer (Fig. 4). The mechanical properties of welded pipe joints are shown in Table 2 .

The sample is prepared according to the standard method, with the use of high-speed grinding wheels and diamond pastes of different dispersion. The structure is detected by chemical etching in a $4 \% \mathrm{HNO}_{3}$ solution in alcohol.

The study is performed with the use of microscopes Neophot - 32 and Versomet, at different magnifications. Microhardness is measured at loads of 100g, on Leco M-400 microhardness tes-

Table 2. Mechanical Properties of Pipe Welds

\begin{tabular}{|l|c|c|c|c|c|}
\hline \multirow{2}{*}{$\begin{array}{c}\text { Type } \\
\text { of steel }\end{array}$} & $\begin{array}{c}\text { Pipes } \\
\text { diameter, } \\
\text { mm }\end{array}$ & \multicolumn{2}{|c|}{$\sigma \mathrm{T}, \mathrm{MPa}$} & \multicolumn{2}{c|}{$\begin{array}{c}\mathrm{KCV},+20{ }^{\circ} \mathrm{C} \\
\mathrm{J} / \mathrm{sm}^{2}\end{array}$} \\
\cline { 3 - 6 } & $\begin{array}{c}\text { Base } \\
\text { metal }\end{array}$ & $\begin{array}{c}\text { Weld } \\
\text { joint }\end{array}$ & $\begin{array}{c}\text { Base } \\
\text { metal }\end{array}$ & $\begin{array}{c}\text { Weld } \\
\text { joint }\end{array}$ \\
\hline 20 & 212 & $\begin{array}{c}508 \ldots . .525 \\
516.5\end{array}$ & $\begin{array}{c}512 \ldots 545 \\
528.5\end{array}$ & $\begin{array}{c}56 . .58 \\
57\end{array}$ & $\begin{array}{c}54 \ldots .58 \\
56\end{array}$ \\
\hline
\end{tabular}

ter. The grain size is determined according to GOST 5639-82. The digital images of microstructures are obtained with the use of Olympus camera.

The joint line is rather striking along the entire height of the weld. The width of the joint line strip ranges within 50-70 microns, in the center; the lattice reaches 200 microns (Fig. 5). The microstructure is a ferrite-perlite mix, where perlite is observed in the form of thin plates along the boundaries of ferrite isolations (lamellar ferrite with ordered and disordered phase 2).

The hardness of the joint line is HV1-2150, 2150, 1990, 2280, 2060, 2280, $2060 \mathrm{MPa}$. The HAZ in the area of overheating (large grain) has a ferrite-pearlite microstructure. Perlite is isolated in the form of individual grains and as part of a ferrite-perlite mix. The grain score in the large grain area corresponds to Nos $6-5$. The hardness is HV1-1930, $2210 \mathrm{MPa}$. The width of the overheating area is $\sim 1200-1300$ microns. Away from the joint line, the structure of the overheated area gets reduced to minute particles; the share of perlite decreases, it appears mainly in the form of individual large grains. In the area of complete recrystallization, the structure is fine-grained (score 9- 


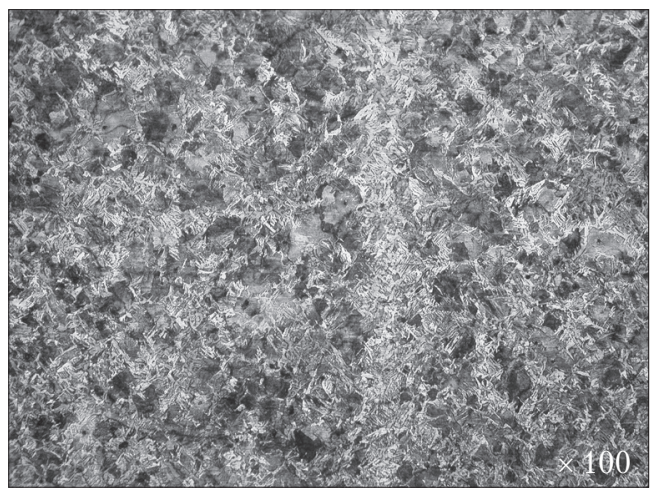

Fig. 5. Line of joint and overheated area

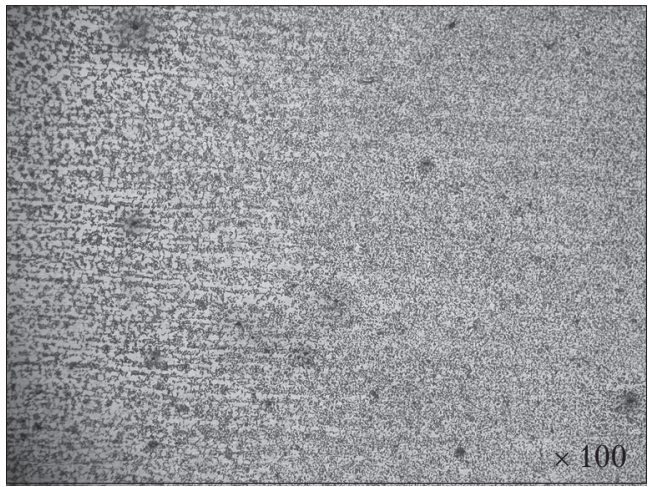

Fig. 6. Complete recrystallization area of HAZ

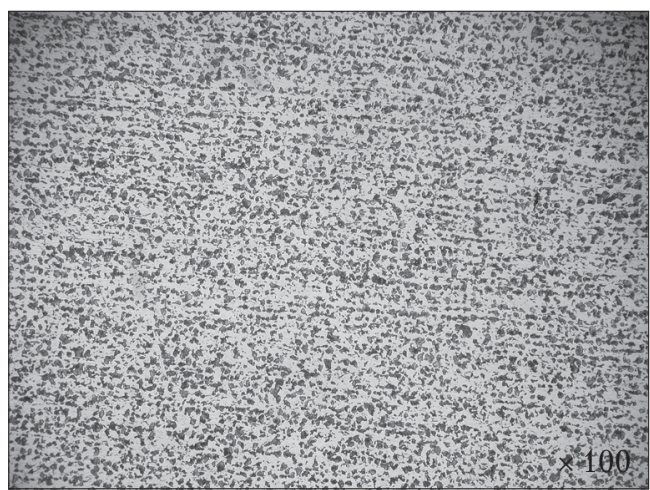

Fig. 7. The structure of the base metal

10 according to GOST 5639-82), of ferrite-pearlite type, with dominating ferrite component. The area width is $1400 \mu \mathrm{m}$, and the hardness is HV11640, $1870 \mathrm{MPa}$ (Fig. 6). The total weld HAZ width is $6800 \mu \mathrm{m}$.

The base metal is ferrite-perlite mix with obvious traces of rolled metal (Fig. 7), the grain size of the base metal is No. 8, according to GOST

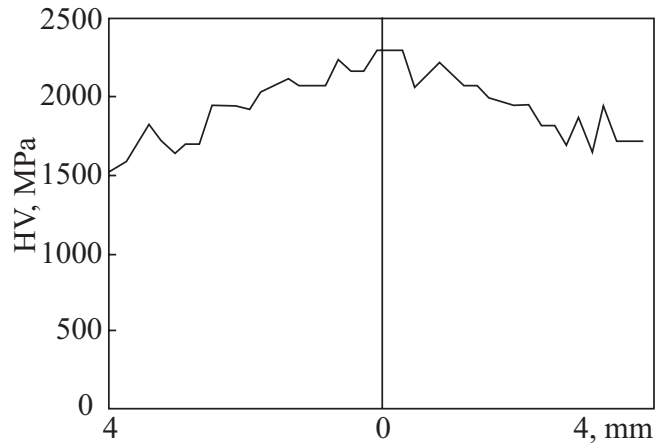

Fig. 8. Hardness along the line of the welded joint: Base metal-HAZ-Line joint-HAZ-Base metal
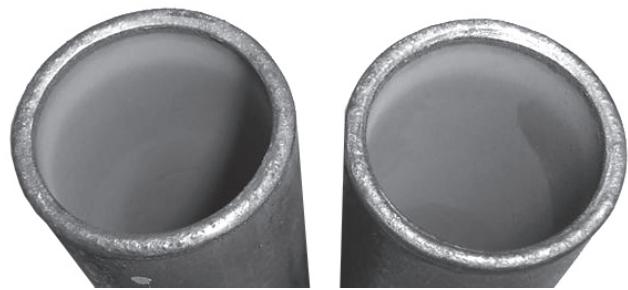

Fig. 9. Appearance of the pipe butts before upset

5639-82. The hardness of the base metal is HV11510-1710 MPa.

The hardness of the welded joint is measured along the line Base metal - HAZ - Joint line $\mathrm{HAZ}$ - Base metal with a load of $100 \mathrm{~g}$ and a step of 500, 300, 200, and $100 \mu \mathrm{m}$ (Fig. 8).

The studies have shown that the behavior of the melt during the pre-upset period has a dominant effect on the formation of joint in the MIAB welding. During this period of hundredths of a second, the surface of the ends is directly exposed to the arc and in contact with the air environment surrounding the welding zone. The area of liquid melt drops may significantly exceed the area of active spots of the arc, which allows us to conclude about the possibility of making high-quality butt joints at fairly long breaks in the arc passage through these areas. This conclusion is the basis for the development of the MIAB technology for tubular parts with a diameter of $212 \mathrm{~mm}$.

Fig. 9 shows samples of the pipe ends after butt heating without upset.

The tests have been performed on welded samples of Steel 20 (diameter $42 \mathrm{~mm}$, wall thickness 


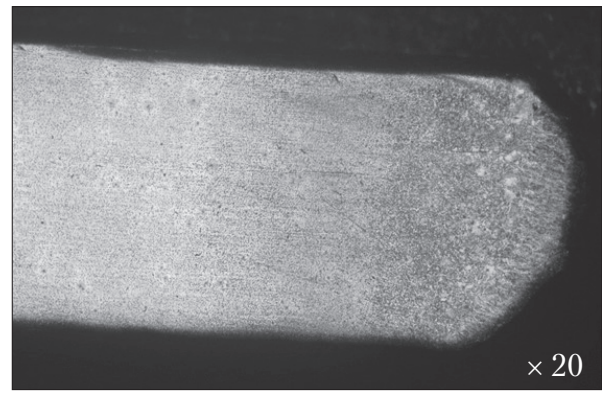

Fig. 10. General view of the fused butt No.1 on the cathode side

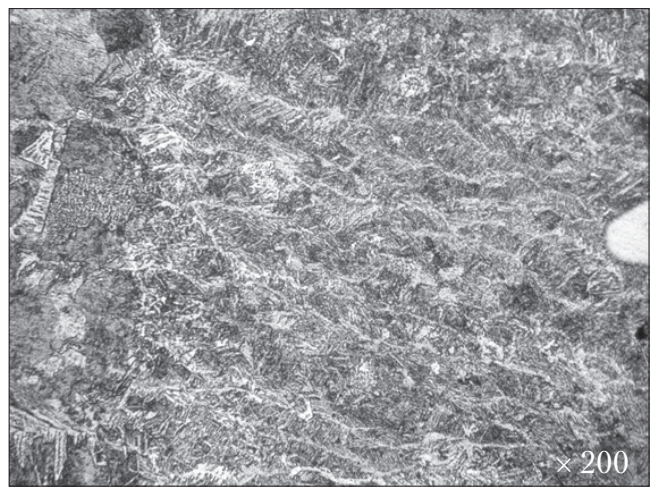

Fig. 11. Microstructure of the fused butt on the cathode side

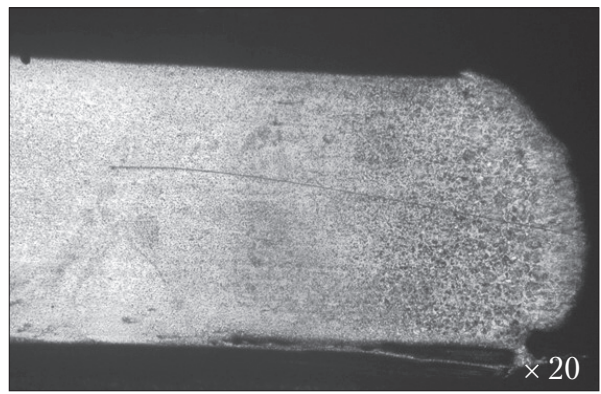

Fig. 12. General view of the fused butt No.2 on the anode side

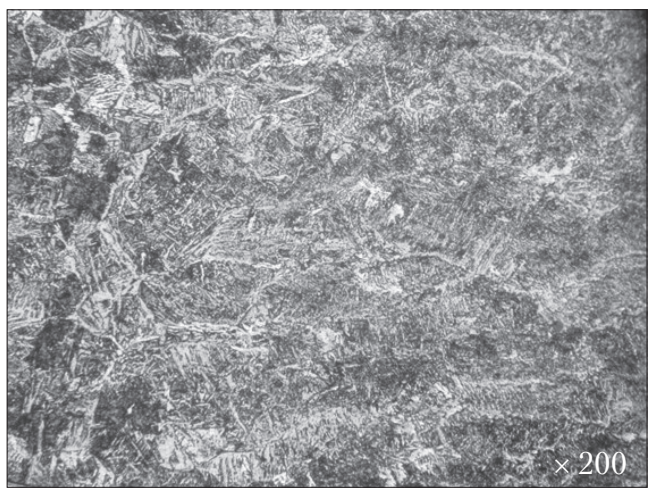

Fig. 13. Microstructure of the fused butt on the anode side

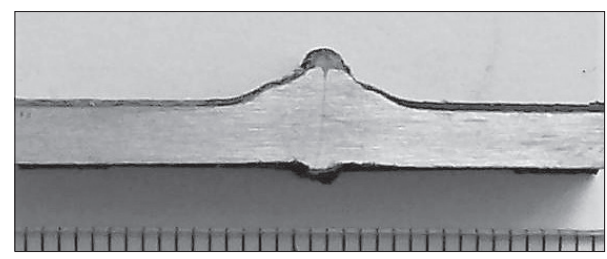

Fig. 14. Macro section of welded joint

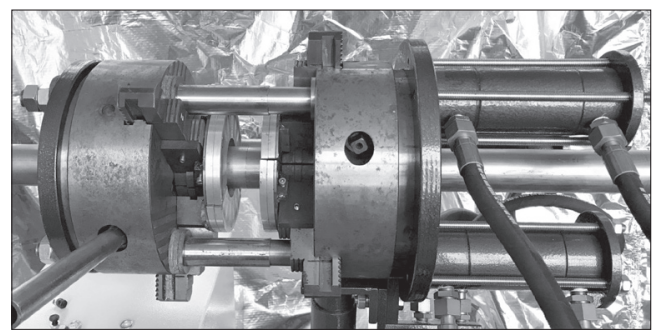

Fig. 15. Device for press welding of tubular parts

$3 \mathrm{~mm})$. The molten sample No.1 on the cathode side (Fig. 10) has been studied. At the edge of the sample, there is cast metal area. The thickness of the section is 650 microns $(0.65 \mathrm{~mm})$, in the center, and 450 microns $(0.45 \mathrm{~mm})$, on the edges.

In the ferrite-perlite structure (Fig. 11), one can see pre-eutectoid ferrite in the form of fringes along the faces of crystals, ferrite with an ordered phase 2 , and a small amount of polyhedral ferrite. The hardness of the metal in the molten area is HV1-2450 - $2640 \mathrm{MPa}$.

The molten sample No.2 on the anode side has been studied (Fig. 12). The structure of the studied areas of the sample is the same as in sample No.1, on the cathode side. It should be noted that there is a larger amount of perlite in the structure. The cast area is shown in Fig. 13. The width is 600 microns, in the center, and 300 microns, on edges. The hardness of the cast metal is HV1-

Table 3. Main Specifications

\begin{tabular}{|l|c|}
\hline \multicolumn{1}{|c|}{ Description } & Value \\
\hline Maximum diameter of a pipe, $\mathrm{mm}$ & 57 \\
Maximum upset force, $\mathrm{kN}$ & 45 \\
Clamping force, maximum, $\mathrm{kN}$ & 90 \\
Productivity, joints per hour & 60 \\
\hline
\end{tabular}

ISSN 2409-9066. Sci. innov. 2021. 17(4) 
$2130-2740 \mathrm{MPa}$. The macrosection of the welded joint is shown in Fig. 14.

The total width of HAZ is 4050 microns.

According to the results of the research, an experimental model of a device for pressure welding of tubular parts has been developed (Fig. 15). The main specifications are presented in Table 3.

During the research, patents for the invention have been obtained [4,5].

The optimal magnetic field induction components for thin-walled tubular parts with a diameter of $212 \mathrm{~mm}$ have been determined.

The main technological parameters: preparation of pipe butts; magnitude and distribution of $\mathrm{CMF}$ induction; the value of the arc voltage during process; programming of the welding current; the rate of closure of the arc gap during upset, which affects the formation of welded joints have been determined.

The influence of the distribution of liquid molten metal on the butt surfaces in the process of heating on the qualitative formation of welded pipe joints has been established.
The metallographic studies have not shown any pores and non-metallic inclusions in the welding joints.

The experimental and industrial technology for welding of thin-walled tubular parts with a diameter up to $212 \mathrm{~mm}$ has been developed.

Experimental and industrial tests of welded tubular parts with a diameter of $212 \times 3.0 \mathrm{~mm}$ for the purpose of their industrial use have been performed and positive results have been obtained.

The welding equipment prototype has been developed and the invention has been patented.

During this period, samples of pipes with a diameter of $212 \times 3 \mathrm{~mm}$ made of steel 20 and steel 35 have been welded. In total, 20 welded joints have been made. The mechanical and metallographic tests have shown that the properties of welded joints are at the level of the properties of the base metal.

Based on the results of the joint tests, Tasco Corporation has confirmed the positive results of research and industrial tests of pipes welded by MIAB technology for industrial use.

\section{REFERENCES}

1. Kuchuk-Yatsenko, S. I., Rudenko, P. M., Gavrish, V. S., Didkovsky, A. V., Antipin, E. V. (2019). Control system for contact welding by fusion of rails in stationary and field conditions to increase the resource and reliability of railways. Technical diagnostics and non-destructive testin, 2, 41-50 [in Russian].

2. Kuchuk-Yatsenko, S. I., Rudenko, P. M., Gavrish, V. S., Didkovsky, A. V., Shvets, V. I., Antipin, E. V., Wojtas, P., Kozlowski, A. (2017). Real-time operational control in information management system for flash-butt welding of rails. Mining informatics automation and electrical engineering, 1, 35-42.

3. Kuchuk-Yatsenko, S. I., Rudenko, P. M., Gavrish, V. S., Didkovsky, O. V., Antipin, E. V. (2016). Statistical control of the process of contact butt welding of rails. Two-level control system. Automatic welding, 5-6, 17-20 [in Russian].

4. Patent of Ukraine No. 116490. Kuchuk-Yatsenko S. I., Kachynskyi V. S, Galahov M. V., Koval M. P., Klimenko V. I. Machine for press welding of pipes [in Ukrainian].

5. Patent of Ukraine No. 36136339. Kuchuk-Yatsenko S. I., Kachynskyi V. S., Galahov M. V., Klimenko V. I., Koval M. P. Machine for press welding of pipes and pipe ends heated by an arc controlled by a magnetic field [in Ukrainian].

Received 08.07.2020

Revised 29.01.2021

Accepted 29.03.2021 
B.C. Качинський (https://orcid.org/0000-0001-9695-6434),

М.П. Коваль (https://orcid.org/0000-0003-2066-3365),

B.I. Клименко (https://orcid.org/0000-0002-8709-5924)

Інститут електрозварювання ім.Є.О.Патона Національної академії наук України, вул. Казимира Малевича,11, Київ, 03650, Україна,

+380 44200 4779, office@paton.kiev.ua

РОЗРОБКА ТЕХНОЛОГЇ ТА СТВОРЕННЯ ДОСЛІДНОГО
УСТАТКУВАННЯ ДЛЯ ЗВАРЮВАННЯ ТИСКОМ
ВИСОКОНАВАНТАЖЕНИХ ТОНКОСТІННИХ РІЗНОРІДНИХ
СТАЛЕВИХ ТРУБЧАСТИХ ДЕТАЛЕЙ
ДЛЯ ПРОМИСЛОВОГО ВИКОРИСТАННЯ

Вступ. Пресове зварювання магнітокерованою дугою (ПЗМд) відрізняється від існуючих дугових способів високою продуктивністю, стабільністю якості зварних з'єднань, високим ступенем механізації та автоматизації технологічного процесу тощо. Зварювання виконується в автоматичному режимі, що значно знижує вплив оператора-зварника на якість зварних з'єднань.

Проблематика. В різних промислових підприємствах та будівництві трубопроводів використовуються труби малих діаметрів до 220 мм. Для виконанні робіт потрібні високопродуктивні методи автоматичного зварювання, які дозволяють отримувати стабільні і надійні зварні з’єднання.

Мета. Підвищення продуктивності праці та економії матеріалів шляхом використання устаткування та технології ПЗМД тонкостінних трубчастих деталей.

Матеріали й методи. Для пресового зварювання використано стальні тонкостінні трубчасті деталі діаметром 42 та 212 мм, з товщиною стінки 2,5-3 мм. Для створення керуючого магнітного поля розроблено магнітні системи для трубчастих деталей діаметром 212 мм. Виконано експериментальні зварювання та досліджено зразки зварних з'єднань труб діаметром 212 мм з товщиною стінки 3 мм. При виконанні досліджень застосовано комп’ютерну реєстрацію та контроль основних параметрів в процесі зварювання.

Результати. Визначено основні технологічні параметри: підготовка торців труб; величину та розподіл індукції КМП; значення напруги дуги; величину й порядок програмування зварювального струму; швидкість закриття дугового проміжку під час осадки, які впливають на формування зварних з'єднань. Розроблено дослідно-промислову технологію зварювання тонкостінних трубчастих деталей діаметром до 212 мм з метою їі промислового використання та концепцію зварювального устаткування. Отримано патенти на винахід.

Висновки. Проведені механічні та металографічні іспити показали, що властивості зварних з'єднань знаходяться на рівні властивостей основного металу. Використання технології ПЗМД дозволить підвищити продуктивність праці та автоматизувати процес зварювання.

Ключові слова: високонавантажені тонкостінні трубчасті деталі, зварювання пресом за допомогою магнітно-керованої дуги, технологія зварювання, формування зварних з'єднань. 